\title{
Corporations and NGOs: When Accountability Leads to Co-optation
}

\author{
Dorothea Baur • Hans Peter Schmitz
}

Published online: 25 November 2011

(C) Springer Science+Business Media B.V. 2011

\begin{abstract}
Interactions between corporations and nonprofits are on the rise, frequently driven by a corporate interest in establishing credentials for corporate social responsibility (CSR). In this article, we show how increasing demands for accountability directed at both businesses and NGOs can have the unintended effect of compromising the autonomy of nonprofits and fostering their co-optation. Greater scrutiny of NGO spending driven by self-appointed watchdogs of the nonprofit sector and a prevalence of strategic notions of CSR advanced by corporate actors weaken the ability of civil society actors to change the business practices of their partners in the commercial sector. To counter this trend, we argue that corporations should embrace a political notion of CSR and should actively encourage NGOs to strengthen "downward accountability" mechanisms, even if this creates more tensions in corporate-NGO partnerships. Rather than seeing NGOs as tools in a competition for a comparative advantage in the market place, corporations should actively support NGO independence and critical capacity.
\end{abstract}

Keywords NGOs - CSR - NGO-business partnerships · Accountability $\cdot$ Co-optation $\cdot$ Watchdogs

\footnotetext{
D. Baur $(\bowtie)$

Institute for Business Ethics, University of St. Gallen,

Tannenstrasse 19, CH-9000 St. Gallen, Switzerland

e-mail: dorothea.baur@unisg.ch

H. P. Schmitz

Moynihan Institute of Global Affairs, Maxwell School of

Syracuse University, Syracuse, USA

e-mail: hpschmit@maxwell.syr.edu
}

\section{Introduction}

Corporations and nongovernmental organizations (NGOs) face increasing pressures for greater accountability. On the one hand, corporate social responsibility (CSR) has increased the demand for NGO-business partnerships as a means to establish credentials of responsible corporate citizenship. On the other hand, NGOs themselves face increasing scrutiny for their actions by a new set of watchdogs, such as Charity Navigator and others. Donors increasingly demand efficient use of resources and promote corporate practices as a means of increasing the effectiveness of NGOs (Pallotta 2008; Edwards 2010). In particular, there has been mounting pressure for NGOs to provide quantifiable results of their activities (Schmitz and Mitchell 2009; Lucea 2010). As both corporations and NGOs face increased public scrutiny, partnerships between them are supposed to represent a "win-win" for both sides, providing enhanced legitimacy to corporations and increased revenue and/or influence to NGOs. Ideally, if both sides become more accountable for their actions and face greater public scrutiny, their overall impact on society should improve over time. In particular, one could expect that if increased collaboration across the for-profit/nonprofit divide can be shown to yield such positive results, civil society could play a heightened role in shaping business practices and could thereby at least partially compensate for diminished governmental capacities in advancing human rights and environmental protection.

Yet, counter to the claims that increased accountability demands will improve business practices and strengthen the voice of NGOs, we argue here that such pressuresespecially when translated into partnerships between corporations and nonprofits-actually increase the likelihood of co-optation and compromise the independence of NGOs. 
We define co-optation as the process of aligning NGO interests with those of corporations and argue that such cooptation manifests itself in sponsoring relationships, labeling agreements, and the personal ties established with corporate leaders. Traditionally, many NGOs engaged in consumer or shareholder activism (Dahan et al. 2010) and use adversarial strategies of litigating against corporate malpractice, conducting critical research, and fostering public education (Utting 2005). But as accountability pressures on corporations and NGOs create incentives to embark on new roles by strengthening the ties between them, it is imperative for both sides to recognize that such ties can undermine the credibility of NGOs as critical partners and thus also diminish the legitimacy gains for corporate actors.

The article is organized as follows. The first section provides a brief overview of the theoretical concept of $\mathrm{co}$ optation and discusses the different roles NGOs can play in their interactions with the corporate sector. We show how co-optation takes place and what types of specific relationships between corporate and nonprofit organizations have recently emerged. Our focus is specifically on sponsoring and labeling arrangements as well as increased personal ties between the corporate and the nonprofit sectors. Although none of these arrangements and mechanisms necessarily must lead to increased co-optation, we argue that they often do because (1) the consequences of such partnerships are rarely fully analyzed by parties before entering into collaborative arrangements and (2) rarely are such partnerships accompanied by explicit efforts to preserve and strengthen the independence of NGOs.

Following the exploration of the "demand side" for possible co-optation, the next section switches perspectives to the "supply side" by showing how increased accountability pressures on NGOs push those organizations into potentially hazardous partnerships with corporations. While NGOs have long struggled to better balance the influence of donors with a desire to increase "downward accountability" to beneficiaries, these endeavors are undermined by an increased array of stakeholders demanding attention "from above." Since NGOs frequently call on others to be more accountable for their actions, "the challenge for NGOs is to show they can put into practice the [accountability] principles they campaign for in others" (Zadek 2003, p. 35). This increased push for NGO accountability has given rise to a whole new set of "watchdog" organizations assessing nonprofits based on overhead spending and efficiency of operations. As NGOs are not only faced with more but also often conflicting demands for accountability, corporate partnerships represent a significant risk for their legitimacy. Increased collaborations with corporate actors (Baur and Palazzo 2011; Ählström and Sjöström 2005; Servos and Marcuello 2007;
Bendell 2005; Hamann and Acutt 2003; Murphy and Bendell 1999) may divert their attention away from other stakeholders; in particular, it may decrease the responsiveness to the needs of beneficiaries.

In the third main section, the article discusses in what ways different notions of CSR either increase or decrease the likelihood of co-optation. In distinguishing between strategic and political notions of CSR, we arrive at recommendations that mitigate co-optation and preserve the independence of NGOs in such partnerships. In short, strategic approaches to CSR view collaboration without changing business practices, for which co-opted NGOs are the most suitable partners, as the best possible outcome of business-nonprofit relations. While such a result may provide corporations with short-term gains in legitimacy, we argue that a more beneficial and long-term approach to these partnerships requires adopting a political understanding of CSR. Instead of co-opting NGOs, corporations with such a notion of CSR take an active interest in promoting the critical distance of their NGO partners and are willing to yield to their demands if they contribute to the solution of a perceived problem. Short-term profit-maximization as the main motive prevalent in the strategic mode of CSR plays a diminished role if corporations accept that NGOs have a crucial role to play in addressing social and political problems. As the boundaries between economic and political spheres are increasingly blurred (Valente and Crane 2010), collaborating with NGOs in an equal partnership enhances the capacity to solve problems that are relevant to both actors. Furthermore, although the decision to collaborate does not depend on it, such an equal partnership might also provide corporations with a competitive advantage in the market place in the long run.

The conclusions summarize the main claims and discuss implications for practice and future research. To convince corporate actors to yield more frequently to the demands by NGOs is only feasible if a political notion of CSR also gains ground in the wide array of self-regulatory agreements such as multi-stakeholder initiatives that among other things aim at regulating the interaction between corporations and civil society. Such relationships are not easy to establish and can only succeed in the long-term if they do not remain isolated instances, but spread across entire business sectors.

\section{Co-optation and the Blurring of the For-Profit/ Nonprofit Distinction}

A first landmark in research on co-optation was set by Philip Selznick, an American professor of law and sociology, as early as 1948. Selznick introduced the concept of co-optation in his article on "Foundations of the Theory of 
Organization," where he characterized it as a "state of tension between formal authority and social power" (Selznick 1948, p. 35). In subsequent decades, co-optation has also been dealt with in critical social theory as well as in cultural studies. Social movement scholars view co-optation as a form of institutionalizing social protest that is engineered by more powerful groups to demobilize the opposition and ensure that their demands are watered down (Piven and Cloward 1977; Lacy 1982; Gamson 1990; Meyer and Tarrow 1998). An example of the more recent usage of the concept depicts the gradual corporatization of the organic food movement as co-optation and states that "a key premise of co-optation theory is that the capitalist marketplace transforms the symbols and practices of countercultural opposition into a constellation of trendy commodities and depoliticized fashion styles that are readily assimilated into the societal mainstream" (Thompson and Coskuner-Balli 2007, p. 136). What follows is that co-optation of social movements is "merely another chapter in the ongoing saga of countercultural cooptation at the hands of corporate capitalism" (Thompson and Coskuner-Balli 2007, p. 136).

In line with this broader discussion about the institutionalization of social movements, co-optation is also being addressed in critical sociology (Shamir 2004) and in critical management studies (Cooke 2003). Yet, although political co-optation has been common theme across many disciplines and is a "built-in condition of movement politics" (Campbell 2001, p. 354), the co-optation of NGOs through corporate partnerships has only more recently garnered more systematic scholarly attention (Trumpy 2008; Utting 2005; Crane and Matten 2007). Scholars have mentioned co-optation in the context of strategic stakeholder involvement (Deetz 2007; Holzer 2008) and have suggested that partnerships between businesses and nonprofits offer too few opportunities to express "divergent opinions that would lead to fundamental changes" (Seitanidi 2010, p. vii). While some argue strongly that abandoning the separation between profit and non-profit world is the only way to effectively address longstanding social and environmental issues (Pallotta 2008), others passionately disagree and view the commercialization of the nonprofit sector as the main reason for the weakening of the sector (Edwards 2008).

We define co-optation as the ability of a corporation to "bring the interests of a challenging group into alignment with its own goals" (Trumpy 2008, p. 480). Co-opted NGOs are gradually absorbed and their organizational identity is compromised (Brinkerhoff 2002, quoted from Selsky 2005). Scholars are particularly concerned about the dangers of co-optation when social movements switch to institutional strategies and trade critical opposition for access to corporate targets. As NGOs enter into corporate partnerships, their focus on developing a working relationship with a stronger corporation may distract from pursuing their mission and it may limit their willingness to use protest and other disruptive strategies, even if such strategies would be more effective for goal attainment. In short, it moves maintaining acceptance to the center of concern (Gamson 1975). While the literature has provided compelling evidence about how co-optation occurs and may even be associated with business-nonprofit partnerships, we argue that what is largely missing from this debate is how accountability pressures on NGOs frequently have the unintended consequence of increasing the likelihood of co-optation.

NGOs_-Watchdogs, Lobbyists, Partners, and Service Providers

NGOs fulfill a broad set of roles as civil society actors and use an equally broad range of strategies to pursue their objectives. Although there is no consensus on how to define and classify NGOs, existing definitions point to a number of similarities distinguishing those actors from political parties or corporations. For Willetts (2002), an NGO is an "independent voluntary association of people acting together on a continuous basis, for some common purpose, other than achieving government office, making money or illegal activities." For Martens (2002), "NGOs are formal (professionalized) independent societal organizations whose primary aim is to promote common goals at the national or the international level." For our purposes, it is key that NGOs are autonomous before entering a corporate partnership (otherwise, they are already co-opted). Our emphasis is primarily on those NGOs that the literature variously labels advocacy or watchdog organizations, i.e. groups that mobilize for policy change rather than engage primarily in service delivery. This distinction also applies to NGO activities towards corporate actors where the goal of policy change is better known by the term "corporate reform" and it is used by the social movement literature when referring to outsider/insider or institutionalized/noninstitutionalized strategies (Trumpy 2008). From a corporate perspective, Holzer (2008) argues that corporate managers distinguish between " 'cooperation-oriented' and 'event-oriented' groups that is, those that the company can deal with and those whose demands are deemed too radical" (p. 56). The latter are perceived to be exclusively interested in challenging corporations without being interested in working with them because they see them only as part of the problem but not of the solution (Den Hond and De Bakker 2007).

For advocacy NGOs, independence is a core credential and sign of legitimacy. Being adversarial and independent from the business it monitors (Muller and Van Tulder 
2006) is crucial for the credibility of self-appointed activists. The same independence from corporate interests is crucial when NGOs assume other roles beyond serving as watchdogs, including consumer activism (i.e. the effort to inform consumers about specific products or companies) or litigation that is the type of activism where courts are used by activists and victims to prosecute corporate malpractice (Utting 2005).

Engaging directly with corporate actors and employing more reformist strategies comes with risks and trade-offs. NGOs may want to have more direct access to decision makers in hopes of affecting corporate behavior from the inside. Other NGOs may be less driven by concerns for effectiveness and more by the constant struggle for organizational survival. Scholte (2004) links the transition from watchdogs to co-opted NGOs to the eagerness of some civil society organizations to obtain funds which in his eyes compromises their autonomy: "These co-opted organizations become voices of-rather than watchdogs overofficial agencies, political parties and powerful individuals in global governance" (p. 224).

As some NGOs are increasingly drawn "into servicedelivery functions and market relations" and "an increasing number (of them, the authors) became part of a growing CSR industry of service providers" (Utting 2005, p. 376), the risk of co-optation rises. With the engagement of NGOs in business-type activities "a whole commercial market develops around shaping, assessing, and consulting on the desired dimensions of social responsibility. A new breed of strategic consultants is also emerging in this new potentially lucrative field" (Shamir 2004, p. 678).

The question that arises is "As and when greater numbers of NGOs begin to think and act more commercially, to what extent will they be able to remain effective corporate watchdogs?" (Murphy and Bendell 1999, p. 8). So far, the literature only provides rather general and sometimes ideologically driven conclusions. Some note rather factually that "business interests and NGOs are becoming more aligned" (Yaziji and Doh 2009, p. 30; also Jamison 1996, p. 234; and Holzer 2008, p. 55), whereas others state that "the social theory dimension of non-profit organisations has "withered in the face of the dominance of capitalist forms of socialisation'" (Jegers and Lapsley 2001, p. 2). Kaldor et al. (2003) claim that NGOs partnering with corporations engage in "corporatization" (p. 9). Yet, it remains still unclear under what conditions co-optation takes place, what strategies NGOs may use to maintain their critical attitude even when entering into cooperative relationships with corporations, and what roles corporations and their notions of CSR play in fostering or inhibiting the co-optation of NGOs.
Drivers of Co-Optation: Active Role of Corporations

Co-optation understood as the loss of NGO autonomy when engaging with corporate partners may be the result of a deliberate strategy of the usually financially much stronger for-profit organization. Lucea (2010) argues that co-optation of those who pursue agendas in conflict with one's own is an important rationale for firms to engage with NGOs. In contrast, NGOs may be motivated to cooperate with firms because they view the idea of CSR as an opening for shaping corporate mindsets from within. The actual outcomes of these interactions remain poorly understood and "the ways and means by which corporations or corporate-friendly non-profit organizations infuse meaning into the very idea of responsibility, and the way such entities symbolically negotiate the scope and substantive contours of the term has hardly been considered" (Shamir 2004, p. 675). Although the initial motives of both sides in these emerging partnerships matter, the dynamics of the interactions can produce different results, including learning on the part of the corporation or the co-optation of the NGO.

Firms may seek collaboration with NGOs in order to control the fallout of civil society mobilization against their unethical behavior and as a way of controlling or anticipating such actions in the future (Dahan et al. 2010). For businesses, being pro-active is crucial in regaining control and "not simply responding or reacting to pressure but itself mobilising to influence control, and lead the agenda of institutional reform" (Utting 2005, p. 375, emphasis added).

A key step towards regaining control of the agenda and lessening the pressure from civil society is the process of stakeholder identification (Mitchell et al. 1997). If corporations elect to work with less critical groups, co-optation is a likely long-term outcome of the interaction. Holzer illustrates this with respect to the relations between Shell and its stakeholders in Nigeria. In a volatile social environment, it was difficult for Shell to engage with stakeholders because the most important among them, i.e. the MOSOP (Movement for the Survival of the Ogoni People), proved to be very elusive and therefore, at least in the beginning, was not recognized by Shell as a stakeholder. Shell preferred to negotiate instead with "more pliable local contacts," i.e. with "conservative leaders who were known as the Shell Chiefs" (Holzer 2008, p. 57). The lesson is that corporations have choices in responding to civil society mobilization and they "may make a virtue of necessity and create suitable and moderate partners themselves, as Shell did with the Shell Chiefs in Nigeria" (Holzer 2008, p. 58). 
The Process of Co-optation: Sponsoring, Labeling and Certification, Personalties

Corporations have forged a wide array of relationships with nonprofits, including various forms of corporate sponsoring, the establishment of certification or labeling agreements, and greater personal ties across the corporatenonprofit divide. In all of these relationships, co-optation of the nonprofit partner is more likely if safeguards against such an outcome are not established early on as part of the partnership.

The most common road to co-optation is corporate sponsoring. Sponsoring is particularly problematic because it can create a resource dependency for NGOs, compromising their ability to challenge corporate behavior. As Shamir (2004) observes there is an increasing number of "corporate-sponsored and corporate-oriented NGOs" which he calls "MaNGOs (Market Non-Governmental Organizations)" (p. 671). According to Shamir, such MaNGOs strive to shape notions of social responsibility in ways that are in accordance with the concerns of business. Corporate sponsoring is particularly attractive as a way of diversifying NGO revenue and when partners are active in separate fields. The example of Save the Children and its quest for corporate support from companies such as CocaCola and Pepsi is particularly instructive in this regard. As long as Save the Children used corporate funding exclusively for its humanitarian and development work abroad, both sides gained financial and reputational benefits and the relationship was harmonious. But when Save the Children began to take an interest in child obesity in the United States and tentatively supported soda tax campaigns mounted in various states by local organizations working on child health issues, the conflict with corporate interests quickly led the Save the Children leadership to decide that "it was too controversial to continue" (Neuman 2010, p. B1). In this case, co-optation is particularly subtle as Save the Children may not have faced any direct pressure from its corporate sponsors, but decided on its own that the soda tax campaign was not a core concern for the organization.

A second process increasing the risk for NGO co-optation is associated with the rapid expansion of certification and labeling agreements in which NGOs directly or indirectly endorse the products a company sells (Murphy and Bendell 1999). Such economic cooperation is characteristic of the increasing commodification of NGO activities (Uphoff 1996, quoted from Murphy and Bendell 1999, p. 8). Covey and Brown (2001) use a case to illustrate how co-optation can arise if an NGO enters into a labeling agreement with a corporation: the Canadian grocery chain Loblaws, without being under pressure from the environmental movement or consumers, proposed an endorsement scheme for environmentally friendly products to an NGO called Pollution Probe (PP). PP was expected to help Loblaws with its expertise and legitimacy to pursue an "innovative marketing venture" (Covey and Brown 2001, p. 10). In return, PP would get a $1 \%$ royalty on green product sales and 1 USD for each "green" T-Shirt or sweatshirt sold. So far, PP had been considered to be a "technically competent watchdog" (Covey and Brown 2001, p. 10), but on collaborating with Loblaws, it stopped to challenge business interests publicly. Its approach to business moved from "finger pointing" to collaboration. Greenpeace, a rival environmental NGO, then publicly challenged the endorsement given by PP. ${ }^{1}$ The problem with the agreement between PP and Loblaws was that it "provided few options for PP to safeguard its own interests, implying that PP did not focus on some key interests it had at stake in the situation. The agreement, for example, had no provision for PP to test the products to be endorsed or to publish results of any tests it might carry out (...) When challenged by Greenpeace, PP could point to no detailed agreement that offered evidence of its continuing independence as a public watchdog" (Covey and Brown 2001, p. 11). As a lesson learned, PP adopted policy criteria for future endorsements in order to avoid co-optation.

And finally, there are also increasing personal ties between profit and nonprofit sector that may lead to cooptation (MacDonald 2008). Increasingly, corporate leaders are recruited by NGOs concerned about resource acquisition and management challenges associated with a more competitive fundraising environment. In Switzerland, the appointment of the general director of Nestlé to the board of trustees of the NGO Swiss Interchurch Aid caused fierce criticism from activists. Although Swiss Interchurch Aid recruited the Nestlé manager in order to increase its access to corporate circles and acquire much needed financial expertise (Meier 2008), critics diagnosed an "institutional incompatibility" between the interests of Nestlé and the ability of the NGO to effectively advocate for human rights, in particular the affordable access to drinking water.

These three examples of intensified corporate-nonprofit relationships involve particular risks and rewards especially for the NGO involved. Co-optation is not necessarily

\footnotetext{
${ }_{1}$ A similar case is currently evolving around the Marine Stewardship Council's (MSC) certification of the Norwegian company Aker BioMarine's krill harvest as environmentally sustainable. Greenpeace criticizes that the MSC has given "an unofficial nod to the basic idea that vacuuming up the tiny life forms forming the foundations of the oceanic ecosystem is an acceptable practice" (Jolly 2010). Greenpeace's criticism convinced the world's leading organic food retailer Whole Foods Market to halt the sales of krill oil because of sustainability issues. This shows that certification does not guarantee a corporation the legitimacy and the hoped-for monetary gains, if a watchdog NGO at the same time chooses to put this corporation on a red list (Whole Foods Magazine Staff 2010).
} 
the end result in any of these interactions, but NGOs rarely enter into such agreements with a full understanding of the possible ramifications and possible costs involved. There is an inherent risk that these types of relationships enhance the existing imbalance of power in favor of the corporations because corporations often engage with NGOs with a deliberate strategy of risk control. Furthermore, direct sponsoring, cooperation on labeling and certification, and recruitment of corporate leaders can raise alarm among supporters and the general public and may also give other NGOs reasons to distance themselves. While working with corporate partners can have many advantages, NGOs have to enter such relationships with an utmost concern for maintaining their own autonomy, and as we will argue later, depending on their notion of CSR, companies are well-advised to abstain from mechanisms that foster cooptation. In the subsequent section, we show how debates about NGO accountability make it even more difficult for civil society groups to maintain their independence and avoid co-optation.

\section{NGO Accountability Debates}

Accountability defines a relationship between an organization and a set of stakeholders and assumes that being responsive to those stakeholders will be beneficial to the NGO and its mandate. Accountability mechanisms for NGOs are "the means through which individuals and organizations are held externally to account for their actions and (...) the means by which they take internal responsibility for continuously shaping and scrutinizing organizational mission, goals, and performance" (Ebrahim 2003a, p. 194). Accountability establishes relationships, defining "the rights of society (or groups/stakeholders within society) and relates to the rights that emerge from the relationship between the accountable organization (the accountor) and the accountee" (Gray et al. 2006, p. 334).

The legitimacy and accountability of transnational nongovernmental organizations (NGOs) has become a major topic of academic and policy debate (Collingwood and Logister 2005; Jordan and van Tuijl 2006; McGann and Johnston 2006; Clark 1995; Edwards and Hulme 1996; Najam 1996; Brett 1993; Brown 2008; Ebrahim 2003b; O'Dwyer and Unerman 2008, 2007; Gray et al. 2006). As NGOs have become increasingly prominent players in global affairs, more questions about their legitimacy and accountability have been raised by scholars and policymakers. Several factors have fed into a growing concern for NGO accountability. First, since NGOs frequently demand accountability from state and corporate actors, they are increasingly asked to meet the same standards of transparency and responsiveness. As transnational NGOs made "accountability politics" (Keck and Sikkink 1998) one of their key weapons in mobilizing for human rights and environmental protection, some of those same demands were thrown back at the non-governmental sector (Zadek 2003, p. 35). Although many NGOs claim to represent the poor and marginalized (Slim 2002; Brown 2008), very few have established effective "bottom-up" ("downward accountability") measures to ensure effective input into decision making from the beneficiaries (Bebbington 2005).

Furthermore, when NGOs act as service providers and substitute for the provision of services by the government, their actions may be a valuable short-term fix, but in the long term, such service provision can undermine the establishment of democratic accountability mechanisms between a government and its own population. NGOs as external actors remain primarily accountable to their donors and their presence usually leads to a fragmentation of service provision as well as greater variation in the quality of services provided compared with the alternative of a strengthened governmental presence (Robinson and White 1997).

Along with the growing presence and role of NGOs, scholars and policymakers became increasingly aware of the challenges associated with shifting funding and responsibilities to the non-governmental sector. The literature on NGO accountability has for some time lamented that NGOs pay too much attention to donors and not enough to beneficiaries and frequently reduce accountability to mere financial accounting without fully involving those affected by their activities (Kilby 2006; Slim 2002). Concerns about organizational survival and increased competition for funding lead to a dominance of "upward" accountability (Chaplowe and Engo-Tjega 2007; Arenas et al. 2009; Brunovan Vijfeijken and Schmitz 2008; Schmitz et al. 2010). Traditional notions of accountability privilege relations to donors and discourage learning from failures (Ebrahim 2005) because donors demand success stories and often care more about how their money is spent than what long-term difference a program has made (Bebbington 2005).

In the context of these complex accountability challenges faced by NGOs, we argue here that businessnonprofit partnerships are likely to undermine the struggle to be more accountable to beneficiaries. As NGOs increasingly add corporate actors to the list of external stakeholders to which they feel directly obliged, donors remain the dominant focus of accountability and beneficiaries will have an even more difficult time to be heard. In the next section, we discuss how the rise of financial watchdogs, such as Charity Navigator, has further intensified this trend by forcing NGOs to pay more attention to issues such as overhead spending and efficiency, rather than responsiveness to those affected by their program activities (Schmitz and Mitchell 2009). 
Upward Accountability and the Trend Towards Financial Metrics

The increasing scrutiny NGOs have faced with regard to their legitimacy and accountability in recent years has led to the emergence of NGO watchdogs and special initiatives that create a diverse and sometimes conflicting set of new incentives. The most controversial result has been an intensified focus on overhead spending that has strengthened donor influence and, as we argue later, is also likely to strengthen the position of business partners and weaken the position of NGOs when collaborating with business partners.

Although the dominance of upward accountability towards donors is nothing new, the recent emergence of an overhead-focused "accountability industry" has further shrunk the autonomy of many NGOs. Strengthening the legitimacy and accountability of NGOs does not necessarily compromise their autonomy and independence and many scholars and practitioners insist that it is an opportunity to "actively construct legitimacy arguments and accountability systems" (Brown 2008, p. 11). Some players in this field, including One World Trust (http:// www.oneworldtrust.org; also: AccountAbility, the Global Reporting Initiative (GRI) and the Humanitarian Accountability Partnership, HAP), seek to promote innovative reporting and accountability systems designed to make accountability an asset in the process of learning from past successes and failures (Ebrahim 2005; Gray et al. 2006). But a competing trend of increased emphasis on overhead spending and financial metrics has narrowed accountability questions to a matter of accounting for output (rather than impact). This trend is most visible in the United States and driven by NGO watchdogs such as Charity Navigator, Guidestar, and the American Philanthropic Institute. While these watchdogs promise potential donors guidance in an increasingly complex landscape of non-profit activities, their primary reliance on financial data perpetuates a dominance of donor interests over those of beneficiaries (Jordan and van Tuijl 2006), threatens the organizational survival of nonprofits (Wing and Hager 2004), and creates incentives to underreport spending on fundraising and administrative costs (Hager and Flack 2004). The accountability perspective advocated by these organizations reflects a desire to find "analogues for the commercial 'bottom line"” (Gray et al. 2006, p. 334), which leads to dysfunctional behavior and distracts from the actual effectiveness of a nonprofit's activities (Lowell et al. 2005). ${ }^{2}$

\footnotetext{
${ }^{2}$ It is important to note that NGO watchdogs such as Charity Navigator have recently embarked on efforts to overhaul their rating systems and supplement financial measures with other criteria, including transparency and reputation among peers and beneficiaries (Ogden 2009).
}

How Upward Accountability Promotes Co-optation

The dominance of upward accountability has, by and large, been strengthened by the appearance of NGO watchdogs during the past decade. Even before Charity Navigator and others began to collect and publish financial data of nonprofits, scholars were long concerned about the “"puppetisation' of NGOs"” (Najam 1996, p. 344) and focused attention on the lack of input by those affected by the activities of NGOs. In this context, strengthening accountability often means even more "emphasis among nonprofits and funders on the upwards and compliance dimensions of accountability" and "skews organizational attention towards the interests of those who control critical resources" (Ebrahim 2010, p. 26).

The emphasis on quantifiable results privileges outputs and distracts from questions of actual impact and democratic input (Eikenberry and Kluver 2004), causing NGOs to become more like corporations as both "populate the same 'area of institutional life' [...] and a common organizational field (DiMaggio and Powell 1983)" (Lucea 2010, p. 116). This emphasis on upward accountability threatens the unique role civil society plays by offering an alternative to markets and the state (hierarchy) as the dominant forms of social organizations. Although an increased concern for legitimacy and accountability offers many opportunities for NGOs to improve their operations, most remain passive and respond defensively to those demands. As a result, other groups, including NGO watchdogs or corporate partners, become the driving force and set the agenda for NGOs. This can easily result in compromising their original mission and fostering co-optation. Michael Edwards (2008) provides evidence for this danger when finding that 22 out of 25 US-based NGO-business joint ventures had experienced "significant conflicts between mission and the demands of corporate stakeholders" (p. 39). The two financially most successful ventures deviated most from their social mission, "reducing time and resources spent on advocacy, weeding out clients who were more difficult to serve, and focusing on activities with the greatest revenue-generating potential" (p. 39). Ebrahim (2010) concurs, arguing that current practices "reward nonprofits for short-term responses with quick and tangible impacts, while neglecting longer-term strategic responses or riskier innovations that can address more systemic issues of social and political" or as we might add: corporate "change" (p. 26). Partnerships with corporations usually reproduce the same material inequality that is a signature of donor-NGO relations and they introduce a market-driven logic into the nonprofit sector. Although this does not inevitably lead to co-optation, the difficulties of establishing meaningful processes of downward accountability indicate that NGOs have to be 
proactive if they want to avoid compromising their autonomy and independence in these collaborative arrangements. This is also in the best interest of their corporate partners because such independence is crucial for the long-term credibility of the collaboration.

\section{Implications for Different Conceptions of CSR}

The increasingly efficiency-driven demand for NGO accountability increases the risks of co-optation of NGOs by corporate interests. However, depending on what notions of CSR corporations adhere to, this control of the NGO agenda must not necessarily lead to a heightened risk of co-optation. In the following, we introduce different notions of CSR that influence in what ways a corporation approaches business-nonprofit partnerships. We distinguish between strategic and political CSR and explain in what ways different approaches either increase the risk of NGO co-optation or strengthen the legitimacy of NGOs by preserving their independence (for different classifications of strands of CSR, see Nijhof et al. 2008; Scherer and Palazzo 2007; Garriga and Melé 2004; Windsor 2006; Carroll 1999).

\section{Strategic Conceptions of CSR}

Strategic notions of CSR are based on the premise that it is the foremost role of companies in a capitalist society to earn and maximize profits. In Milton Friedman's (1970) famous version of this view "the social responsibility of business is to increase its profits." More recent proponents of a strategic notion have moved away from entirely reducing social responsibility to profit making, but still insist that it primarily has value as a "source of opportunity, innovation, and competitive advantage" (Porter and Kramer 2006, p. 80). This perspective no longer assumes that making profits is the only way of being socially responsible, but it seeks to identify those specific opportunities where businesses can gain from a partnership without having to compromise any of their core interests and goals. This notion of "responsible profitability" (see, e.g., Carroll 1991) offers opportunities for businesses to contribute to "worthy social causes" (Shamir 2004, p. 683).

Proponents of strategic CSR share a "harmonistic world-view" (Ulrich 2008, p. 402) that de-emphasizes potential conflict in which socially responsible behavior would be preferable in principle but does not pay off in terms of profits. Still, different versions of strategic CSR have very different consequences for potential nonprofit partners. A purely charitable approach entails giving donations for social or cultural purposes after profits, whereas a more proactive approach to philanthropy may entail more meaningful interactions between businesses and nonprofits having potential effects on corporate behavior (Ulrich 2008). In both versions, instrumental rationality prevails and "doing good" always depends on "doing well" (Shamir 2004). There is thus no intrinsic reason for CSR that would derive from the assumption that corporations do it because it "is the right thing to do" (Margolis and Walsh 2003, p. 282). Instead, the underlying motivation for strategic CSR is the self-interest of corporations (Matten and Crane 2005).

The harmonistic worldview behind strategic CSR manifests itself in the interactions between corporations and NGOs. The selection and identification of partner NGO is driven by the question whether there is "a potential for a win-win situation for both/all parties?" (Muller and Van Tulder 2006, p. 22). A win-win situation requires that the stakeholder engagement is non-adversarial. Apparently, as Shamir (2004) argues, corporate executives who received their CSR training from market-oriented NGOs found themselves reluctant to see CSR as a "site of potential conflict between core business practices and social issues" (p. 681). Instead, they were trained to embrace CSR as a business opportunity that "has to be managed with an eye to the strategies, goals and methods of the business enterprise as a whole" (p. 684).

A strategic CSR approach offers only limited opportunities for NGOs to transform corporate behavior. In most cases, it likely reflects a strategy of risk control, whereby a corporation seeks to pull the teeth from watchdog NGOs and align their interests with the economic interests of the corporation (Nijhof et al. 2008). Such co-optation can enhance corporate reputation without compromising the business model and profitability. For example, Coca-Cola successfully used a strategic notion of CSR in dealing with a Greenpeace campaign mounted against its refrigeration practices between 1998 and 2005: "Co-optation occurs if Coca-Cola receives credit for becoming more environmentally friendly without actually altering its actions in any way" (Trumpy 2008, p. 488). Under such circumstances, the co-opted NGO can be used to endow the corporation "with increased legitimacy and reestablish stability" (Trumpy 2008, p. 486) without undertaking corporate reform or giving an NGO real influence.

There are different models of strategic CSR, ranging from a purely profit-driven view to allowing for some altruistic motives being added to corporate behavior. We argue here that current trends pushing financial notions of NGO accountability increase the likelihood of co-optation, in particular when corporate partners adhere to a strategic CSR model. By avoiding partnerships with critical NGOs and by largely subjecting philanthropic efforts to the goal of making profits, strategic CSR avoids or neutralizes a 
direct influence of NGOs on corporate practices. In the context of shifting demands for NGO accountability, such partnerships lack an expressed goal of fostering or at least maintaining the independence of NGOs and cultivating open debate that may question corporate practices. Instead, collaboration based on strategic CSR is more likely to strengthen the obligations NGOs have towards donors and corporate partners. NGOs may gain financial resources in such partnerships, but they are not likely to influence the behavior of their usually much wealthier partner.

\section{Political Conceptions of CSR}

Beyond the dominant strategic notion of CSR, some scholars have developed an important alternative strand of CSR that views the business firm not only as an economic but increasingly also a political actor in a globalizing world (e.g. Scherer et al. 2006; Scherer and Palazzo 2007; Wettstein 2009; Crane and Matten 2007; Valente and Crane 2010; Moon et al. 2005). Political CSR puts greater emphasis on one of the original reasons for advancing the CSR agenda, namely, to hold multinational corporations accountable for the increasing power and influence they exercise in their daily decision making (Garriga and Melé 2004; Carroll 1999; Utting 2005).

The extent of the power that corporations hold is mirrored in the claims that are raised towards them. Multinational corporations are not only held accountable for how they produce goods or services for the market but also for how they respond to diverging expectations expressed by their shareholders, employees, suppliers, the communities in which they operate, and the state and the general public. As a growing number of corporations are under pressure to address negative ecological and social external effects of their operations (Ulrich 2008), the CSR agenda is increasingly broadening to include direct responsibilities regarding the promotion of environmental, labor, and human rights standards (Walsh et al. 2003). These goals are pursued through self-regulation (codes of conduct) as well as standard-setting and -monitoring by external agents, including the GRI, the Fair Labor Association (FLA), AccountAbility 1000 (AA 1000), Social Accountability 8000 (SA 8000), or the UN Global Compact (Gilbert and Rasche 2007, p. 187).

Similar to the case of strategic CSR, there are more principled and more pragmatic variants of a more political understanding of CSR. More principled variants adopt that corporations adopt responsibility for their environmental and societal impacts because they inherently believe this to be the right thing to do (Margolis and Walsh 2003; Nijhof et al. 2008; Vachani et al. 2009). More pragmatic versions do not assume such principled commitment, but simply claim that corporations engage in CSR whenever governments are not providing public services needed to sustain particular business activities (Valente and Crane 2010). In either case, corporations then take on significant responsibilities that likely entail sharing power with local communities and NGOs.

Political CSR explicitly ascribes NGOs the role of watchdogs that publicly raise concerns over the legitimacy of corporate activities (Scherer and Palazzo 2007, p. 1112). Broadly speaking, political CSR does not shy the "scrutiny of open public debate, review, and determination" (Fung 2003, p. 52) and in contrast to the strategic notion of CSR, the political notion is not afraid of conflict because its aim is not to create "value-based homogeneity" (Scherer and Palazzo 2007 , p. 1114) but rather to effectively contribute to the solution of a perceived societal or environmental problem, even if it may not directly contribute to the generation of profits. Corporations that adhere to political CSR may even be willing to undertake corporate reform and yield to the challenging group if necessary, that is, if it contributes to the solution of a perceived problem (Trumpy 2008). One could then say that political CSR acknowledges and to a certain extent even relies on the intrinsic value of watchdog NGOs because they are seen as legitimate actors with valuable knowledge on the problems around which CSR centers.

A convincing account of how a corporation that acknowledges the intrinsic value of NGOs argues is presented by an external affairs adviser at Shell. This adviser describes the delicate balance of Shell's relationship with Amnesty International as follows:

We value their independence and the independent integrity as much as other people do. It's their most precious resource and we must never do anything to compromise that. So, in some regard, we don't want to get too pally with Amnesty because that would undermine their very value in the first place. (Holzer 2008, p. 56)

If we translate this statement into the language of this article it means: Shell will do anything not to co-opt Amnesty International because they recognize their intrinsic value as independent and integer watchdogs.

What are the implications of political CSR for NGO accountability? In contrast to strategic CSR, political CSR does not benefit from the current trend towards emphasizing the upward accountability of NGOs. On the one hand, corporations with a political notion of CSR can be expected to care strongly about NGO accountability because it would seem logical for them to have their legitimacy judged by strong and independent actors. On the other hand, such corporations find their endeavors undermined if more NGOs adapt themselves to upward accountability and if upward accountability becomes an increasingly accepted standard for NGO accountability. 
We do expect that corporations with a political notion of CSR abstain from co-opting measures that might distort the agenda of watchdog NGOs. Instead, they are most likely to leave them certain "room to manoeuvre" with regard to how they achieve their mission and they might promote the accountability of the NGOs with whom they engage towards their beneficiaries. After all, it is in the enlightened self-interest of such corporations to contribute to a shifting perspective on NGO accountability and to support the above-mentioned aspirations of NGO watchdogs to overhaul their rating systems towards a more beneficiaryoriented perspective on NGO accountability.

\section{Conclusions}

Bridging the literatures on CSR and NGO accountability adds distinct insights into the challenges associated with business-nonprofit partnerships. Critical evaluations of such partnerships have for some time questioned the efficacy of such arrangements from an NGO perspective and an extensive literature has also described in what ways social movement institutionalization can lead to co-optation. This article adds to these claims a more specific understanding of how increasing accountability demands on both businesses and nonprofits can have unintended negative consequences. In particular, pressures on NGOs to limit overhead spending and to emphasize financial accounting create unique vulnerabilities for co-optation when entering partnerships with corporate actors.

From a business perspective, the approach to CSR has also a powerful effect on the likelihood of NGO co-optation. A narrowly defined strategic view conceptualizes corporations only as economic actors and largely ignores the broader political implications of their activities. When a corporation follows such a perspective in entering a business-nonprofit partnership, co-optation is more likely because the independence of the partner organization is not an explicit goal of the relationship established. In contrast, if a corporation takes seriously its role and responsibilities as a political actor, it is more open to weighing goals other than profitability in its decision making. Political CSR offers a valuable perspective by exhorting businesses to accept the critical role of watchdog NGOs as an inherent part of their social responsibility.

If not all solutions to social problems are market-driven, then NGOs can play an important role in providing corporations with needed information and policy options that contribute not only to the solution of a perceived environmental or social problem but also to the long-term sustainability and expansion of their business. In return, this requires corporations to be more accepting of feedback which may, in the short term, not generate additional profits or even create costs. In this model, businesses would also take a stronger interest in the strengthening and independence of those NGOs that can provide the most credible information, even if it challenges their corporate practices. In particular, businesses would endeavor to use partnerships with nonprofits to strengthen "downward accountability" and work actively against dependence on donors. Co-opted partner NGOs are unlikely to provide continuous feedback that allows a corporation to adapt its business practices and preempt problems in the future. Respecting or even enhancing the independence of NGO partners also creates more credibility with the general public and might even provide a competitive advantage in the market place. Corporate partners also need to engage in debates around NGO accountability and explicitly challenge the current model as promoted by NGO watchdogs that is entirely focused on efficiency and overhead spending. Corporations should join forces with innovative reporting and accountability systems that shift attention towards the actual effectiveness and impact of NGO activities.

While this article broadly sketches out some of the possible outcomes of business-nonprofit partnerships, future research should investigate more systematically in what ways different CSR approaches affect those collaborations and the NGO partners. We expect that the particular type of industry and substance of collaboration play a crucial role in determining not only the willingness of a business to adopt a broader understanding of CSR but also the possible gains for both parties. Future research should not only focus on variation on the corporate side but also take more seriously differences among NGO partners and their strategies. For example, additional research is needed to better understand what type of strategies targeting corporate actors are most likely to elicit a response leading to sustainable change along the demands put forth by NGOs.

The idea that corporations take on greater and more politically meaningful responsibilities as well as share power with NGOs and local communities remains for many an idealistic proposition. Even among corporations that follow a more political notion of CSR, pragmatic motivations are likely to dominate. The main challenge we see emerges early in the interaction between corporation and NGO. By definition, only NGOs with a rather antagonistic agenda can be co-opted and any campaign waged against a corporation will initially result in an exchange of attacks, denials, and rejection. The question is how both parties can move beyond this initial stage and develop sufficient common ground to engage in a relationship of critical collaboration. Such an engagement will always be strained by the different organizational cultures separating the forprofit from the nonprofit world. Success of a more political CSR approach also depends on a relatively rapid diffusion 
of the concept across the entire industry and on its manifestation in voluntary frameworks as provided by multistakeholder initiatives, forums, or councils that aim at regulating the interaction between corporations and civil society actors. If not, NGOs may temporarily succeed in affecting the behavior of selected individual businesses, but those corporations disappear or break their agreements in the long run because of competitive pressure. Ensuring that certain standards of corporate conduct are evenly applied across sectors likely requires moving beyond the particular business-nonprofit partnership to the self-regulatory level of multi-stakeholder initiatives and to the regulatory level of nation states and international agreements.

\section{References}

Ählström, J., \& Sjöström, E. (2005). CSOs and business partnerships: Strategies for interaction. Business Strategy and the Environment, 14(4), 230-240.

Arenas, D., Lozano, J. M., \& Albareda, L. (2009). The role of NGOs in CSR: Mutual perceptions among stakeholders. Journal of Business Ethics, 88(1), 175-197.

Baur, D., \& Palazzo, G. (2011). The moral legitimacy of NGOs as partners of corporations. Business Ethics Quarterly, 21(4), 579-604.

Bebbington, A. (2005). Donor-NGO relations and representations of livelihood in nongovernmental aid chains. World Development, 33(6), 937-950.

Bendell, J. (2005). In whose name? The accountability of corporate social responsibility. Development in Practice, 15(3), 362-374.

Brett, E. A. (1993). Voluntary agencies as development organizations: Theorizing the problem of efficiency and accountability. Development and Change, 24(2), 269-304.

Brinkerhoff, J. M. (2002). Government-nonprofit partnership: A defining framework. Public Administration and Development, 22(1), 19-30.

Brown, L. D. (2008). Creating credibility: Legitimacy and accountability for transnational civil society. Sterling, VA: Kumarian Press.

Bruno-van Vijfeijken, T., \& Schmitz, H. P. (2008). Accountability without learning: A cross-sectoral analysis of transnational NGOs. Syracuse: Transnational NGO Initiative/Moynihan Institute of Global Affairs.

Campbell, D. (2001). Conviction seeking efficacy: Sustainable agriculture and the politics of co-optation. Agriculture and Human Values, 18, 353-363.

Carroll, A. B. (1991). The pyramid of corporate social responsibility: Toward the moral management of organizational stakeholders. Business Horizons, 34(4), 39-48.

Carroll, A. B. (1999). Corporate social responsibility. Evolution of a definitional construct. Business \& Society, 38(3), 268-295.

Chaplowe, S. G., \& Engo-Tjega, R. B. (2007). Civil society organizations and evaluation: Lessons from Africa. Evaluation, 13(2), 257-274

Clark, A. M. (1995). Non-governmental organizations and their influence on international society. Journal of International Affairs, 48(2), 507-525.

Collingwood, V., \& Logister, L. (2005). State of the art: Addressing the INGO 'legitimacy deficit'. Political Studies Review, 3(2), $175-192$.
Cooke, B. (2003). A new continuity with colonial administration: Participation in development management. Third World Quarterly, 24(1), 47-61.

Covey, J. \& Brown, L. D. (2001). Critical cooperation: An alternative form of civil society-business engagement. IDR Reports 17 (1).

Crane, A., \& Matten, D. (2007). Business ethics: Managing corporate citizenship and sustainability in the age of globalization. Oxford: Oxford University Press.

Dahan, N. M., Doh, J. P., \& Teegen, H. (2010). Role of nongovernmental organizations in the business-government-society interface. Special issue overview and introductory essay. Business \& Society, 49(1), 20-34.

Deetz, S. (2007). Corporate governance, corporate social responsibility, and communication. In S. May, G. Cheney, \& J. Roper (Eds.), The debate over corporate social responsibility (pp. 267-277). Oxford: Oxford University Press.

Den Hond, F., \& De Bakker, F. G. A. (2007). Ideologically motivated activism: How activist groups influence corporate social change behavior. Academy of Management Review, 32(3), 901-924.

Ebrahim, A. (2003a). Making sense of accountability: Conceptual perspectives for northern and southern nonprofits. Nonprofit Management and Leadership, 14(2), 191-212.

Ebrahim, A. (2003b). Accountability in practice: Mechanisms for NGOs. World Development, 31(5), 813-829.

Ebrahim, A. (2005). Accountability myopia: Losing sight of organizational learning. Nonprofit and Voluntary Sector Quarterly, 34(1), 56-87.

Ebrahim, A. (2010). The many faces of nonprofit accountability. Harvard business school working paper (10-069).

Edwards, M. (2008). Just another emperor? The myths and realities of philantrocapitalism. New York: DEMOS/Young Foundation.

Edwards, M. (2010). Small change. Why business won't save the world. San Francisco: Berrett-Koehler Publishers.

Edwards, M., \& Hulme, D. (1996). Too close for comfort? The impact of official aid on nongovernmental organizations. World Development, 24(6), 961-973.

Eikenberry, A. M., \& Kluver, J. D. (2004). The marketization of the nonprofit sector: Civil society at risk. Public Administration Review, 64(2), 132-140

Friedman, M. (1970, September 13). The social responsibility of business is to increase its profits. The New York Times Magazine.

Fung, A. (2003). Deliberative democracy and international labor standards. Governance, 16(1), 51-71.

Gamson, W. (1975). The strategy of social protest. Homewood, IL: Dorsey Press.

Gamson, W. A. (1990). The strategy of social protest. Belmont, CA: Wadsworth.

Garriga, E., \& Melé, D. (2004). Corporate social responsibility theories: Mapping the territory. Journal of Business Ethics, 53(1-2), 51-71.

Gilbert, D. U., \& Rasche, A. (2007). Discourse ethics and social accountability: The ethics of SA 8000. Business Ethics Quarterly, 17(2), 187-216.

Gray, R., Bebbington, J., \& Collison, D. (2006). NGOs, civil society and accountability: Making the people accountable to capital. Accounting, Auditing \& Accountability Journal, 19(3), 319-348.

Hager, M. A., \& Flack, T. (2004). The pros and cons of financial efficiency standards. Washington, D.C: Nonprofit Overhead Cost Project/Urban Institute.

Hamann, R., \& Acutt, N. (2003). How should civil society (and the government) respond to 'corporate social responsibility'? A critique of business motivations and the potential for partnerships. Development Southern Africa, 20(2), 255-270.

Holzer, B. (2008). Turning stakeseekers into stakeholders: A political coalition perspective on the politics of stakeholder influence. Business \& Society, 47(1), 50-67. 
Jamison, A. (1996). The shaping of the global environmental agenda: The role of nongovernmental organisations. In S. Lash, B. Szerszynski, \& B. Wynne (Eds.), Risk, environment and modernity. Towards a new ecology (pp. 224-245). London: Sage.

Jegers, M., \& Lapsley, I. (2001). Making sense of non-profit organisations. Financial Accountability and Management, $17(1), 1-3$.

Jolly, D. (2010, June 22). Krill Harvest certification upsets conservationists. New York Times.

Jordan, L., \& van Tuijl, P. (2006). NGO accountability. Politics, principles, innovations. London: Earthscan.

Kaldor, M., Anheier, H., \& Glasius, M. (2003). Global civil society 2003. Oxford: Oxford University Press.

Keck, M. E., \& Sikkink, K. (1998). Activists beyond borders. Advocacy networks in international politics. Ithaca: Cornell University Press.

Kilby, P. (2006). Accountability for empowerment: Dilemmas facing non-governmental organizations. World Development, 34(6), 951-963.

Lacy, M. G. (1982). A model of cooptation applied to the political relations of the United States \& American Indians. Social Science Journal, 19(1), 24-36.

Lowell, S., Trelstad, B., \& Meehan, B. 2005. The ratings game. Evaluating the three groups that rate the Charities. Stanford Social Innovation Review, 39-45.

Lucea, R. (2010). How we see them versus how they see themselves a cognitive perspective of firm-NGO relationships. Business \& Society, 49(1), 116-139.

MacDonald, C. (2008). Green, Inc.—an environmental insider reveals how a good cause has gone bad. Guilford CT: The Lyons Press.

Margolis, J. D. \& Walsh, J. P. 2003. Misery loves companies: Rethinking social initiatives by business. Administrative Science Quarterly (48):268-305.

Martens, K. (2002). Mission impossible? Defining nongovernmental organizations. Voluntas: Journal of Voluntary and Nonprofit Organizations, 13(3), 271-285.

Matten, D., \& Crane, A. (2005). Corporate citizenship: Toward an extended theoretical conceptualization. Academy of Management Review, 30(1), 166-179.

McGann, J., \& Johnston, M. (2006). The power shift and the NGO credibility crisis. International Journal of Not-for-Profit Law, $8(2), 65-77$.

Meier, M. (2008, 22. 7.). Nestlé-Chef sorgt mit Heks-Job für Wirbel. Tages-Anzeiger.

Meyer, D. S., \& Tarrow, S. (1998). A movement society: Contentious politics for a new century. In D. S. Meyer \& S. Tarrow (Eds.), The social movement society: Contentious politics for a new century (pp. 1-28). Lanham, MD: Rowman and Littlefield.

Mitchell, R. K., Agle, B. R., \& Wood, D. J. (1997). Toward a theory of stakeholder identification and salience: Defining the principle of who and what really counts. Academy of Management Review, 22(4), 853-886.

Moon, J., Crane, A., \& Matten, D. (2005). Can corporations be citizens? Corporate citizenship as a metaphor for business participation in society. Business Ethics Quarterly, 15(3), 429-453.

Muller, A. \& Van Tulder, R. (2006). Partnerships, power and equity in global commodity chains: A 'rough guide' to partnerships for development. http://www.agri-profocus.nl/docs/2007082815160 24001.pdf. Accessed January 5, 2010.

Murphy, D. F., \& Bendell, J. (1999). Partners in Time? Business, NGOs and sustainable development. Geneva: UNRISD.

Najam, A. (1996). NGO accountability: A conceptual framework. Development Policy Review, 14(1), 339-353.

Neuman, W. (2010, December 15). Save the children breaks with soda tax effort. The New York Times.
Nijhof, A., de Bruijn, T., \& Honders, H. (2008). Partnerships for corporate social responsibility: A review of concepts and strategic options. Management Decision, 46(1), 152-167.

O'Dwyer, B., \& Unerman, J. (2007). From functional to social accountability. Transforming the accountability relationship between funders and non-governmental development organisations. Accounting, Auditing \& Accountability Journal, 20(3), 446-471.

O'Dwyer, B., \& Unerman, J. (2008). The paradox of greater NGO accountability: A case study of Amnesty Ireland. Accounting, Organizations and Society, 33(7-8), 801-824.

Ogden, T. 2009. The worst (and best) way to pick a charity this year. Experts explain that overhead ratios and executive salaries are a red herring. http://www.philanthropyaction.com/nc/the_best_ way_to_pick_a_charity_this_year/. Accessed March 2010.

Pallotta, D. (2008). Uncharitable. How restraints on nonprofits undermine their potential. Boston: Tufts University Press.

Piven, F. F., \& Cloward, R. (1977). Poor people's movements. New York: Pantheon.

Porter, M. E., \& Kramer, M. R. (2006). Strategy \& society: The link between competitive advantage and corporate social responsibility. Harvard Business Review, 84(12), 78-92.

Robinson, M., \& White, G. (1997). The role of civic organizations in the provision of social services. Helsinki: United Nations University.

Scherer, A. G., \& Palazzo, G. (2007). Toward a political conception of corporate responsibility-business and society seen from a Habermasian perspective. Academy of Management Review, 32(4), 1096-1120.

Scherer, A. G., Palazzo, G., \& Baumann, D. (2006). Global rules and private actors: Toward a new role of the transnational corporation in global governance. Business Ethics Quarterly, 16(4), 505-532.

Schmitz, H. P., \& Mitchell, G. (2009). Bracing for Impact. Monday Developments, 27(4), 20-22.

Schmitz, H. P., Raggo, P., \& Bruno-van Vijfeijken, T. (2010). New standards, old habits: Transnational NGO leaders' perspectives on the what for, to whom, and how of being accountable. Syracuse: Moynihan Institute of Global Affairs.

Scholte, J. A. (2004). Civil society and democratically accountable global governance. Government and Opposition, 39(2), 211-233.

Seitanidi, M. M. (2010). The politics of partnerships. A critical examination of nonprofit-business partnerships. New York: Springer.

Selznick, P. (1948). Foundations of the theory of organization. American Sociological Review, 13(1), 25-35.

Servos, C. M., \& Marcuello, C. (2007). NGOs, corporate social responsibility, and social accountability: Inditex vs. clean clothes. Development in Practice, 17(3), 393-403.

Shamir, R. (2004). The de-radicalization of corporate social responsibility. Critical Sociology (Brill Academic Publishers), 30(3), 669-689.

Slim, H. (2002). By what authority? The legitimacy and accountability of NGOs. The International Council on Human Rights Policy international meeting on 'global trends and human rightsBefore and after September 11', Geneva; January 10-12, 2002.

Thompson, C. J., \& Coskuner-Balli, G. (2007). Countervailing market responses to corporate co-optation and the ideological recruitment of consumption communities. Journal of Consumer Research, 34(2), 135-152.

Trumpy, A. J. (2008). Subject to negotiation: The mechanisms behind co-optation and corporate reform. Social Problems, 55(4), 480500.

Ulrich, P. (2008). Integrative economic ethics. Foundations of a civilized market economy. Cambridge: Cambridge University Press. 
Uphoff, N. T. (1996). Why NGOs are not a third sector: A sectoral analysis with some thoughts on accountability, sustainability and evaluation. In M. Edwards \& D. Hulme (Eds.), Beyond the magic bullet: NGO performance and accountability in the post-cold war world (pp. 23-39). West Hartford: Kumarian Press.

Utting, P. (2005). Corporate responsibility and the movement of business. Development in Practice, 15 (3 \& 4), 375-388.

Vachani, S., Doh, J. P., \& Teegen, H. (2009). NGOs' influence on MNEs' social development strategies in varying institutional contexts: A transaction cost perspective. International Business Review, 18(5), 446-456.

Valente, M., \& Crane, A. (2010). Public responsibility and private enterprise in developing countries. California Management Review, 52(3), 52-78.

Walsh, J. P., Weber, K., \& Margolis, J. D. (2003). Social issues and management: Our lost cause found. Journal of Management, 29, $859-881$.

Wettstein, F. (2009). Multinational corporations and global justice. Human rights obligations of a quasi-governmental institution. Stanford: Stanford University Press.
Whole Foods Magazine Staff. (2010). Whole foods says no to krill oil sales, Aker confirms MSC certification. http://www.wholefoods magazineonline.com/news/green-news/whole-foods-says-no-krilloil-sales-aker-confirms-msc-certification. Accessed December 26, 2010.

Willetts, P. (2002). What is a non-governmental organization? In UNESCO (Ed.), Encyclopedia of life support systems. Oxford: Eolss Publishers.

Windsor, D. (2006). Corporate social responsibility: Three key approaches. Journal of Management Studies, 43(1), 93-114.

Wing, K., \& Hager, M. A. (2004). Getting what we pay for. Low overhead limits nonprofit effectiveness. Washington, DC: Nonprofit Overhead Cost Project/Urban Institute.

Yaziji, M., \& Doh, J. P. (2009). NGOs and corporations: Conflict and collaboration. Cambridge, UK: Cambridge University Press.

Zadek, S. (2003, September). In defense of non-profit accountability. Ethical Corporation Magazine, 34-36. 